\title{
Impact of an Organizational Culture Towards Job Performance: A Study on Colombo District Multinational Banking Employees
}

\author{
D.A.Y. Codipily ${ }^{1}$ \& D.M.T.D. Dissanayake ${ }^{2}$ \\ ${ }^{1,2}$ Department of Business Management \\ Faculty of Business Studies \& Finance \\ Wayamba University of Sri Lanka \\ Kuliyapitiya \\ SRI LANKA \\ Devmi.anuththar123@gmail.com ${ }^{1}, \underline{\text { tanyad@wyb.ac.lk }}$
}

\begin{abstract}
Banks play a critical role within the Sri Lankan financial system, as they are engaged in provision of liquidity to the entire economy, while transforming the risk characteristics of assets. This study is on defining and measuring of organizational culture and its impact on the employee performance. The objective of this study was to demonstrate conceptualization, measurement and examine various concepts on organization culture and performance. Therefore, the present research used cultural variables of values, believes, norms and subcultures and the impact on employee job performance. For the purpose of analyzing the data, 100 respondents who were selected by using Stratified random sampling, from 5 multinational banks in Colombo district. Pearson Correlation and Liner regression were used as the tools to measure the performance. According to this study there was strong positive relationship between organizational norms and employee job performance. And there were moderate positive relationships between organizational values, believes, subcultures and job performance. Research shows that if employee were committed and having the same norms and value as per organizations have, can increase the performance toward achieving the overall organization goals. And organizational norms were most influential variable to employee job performance. Managers and leaders are recommended to develop the strong culture in the organization to improve the overall performance of the employees and organization.
\end{abstract}

Keywords: Organizational Culture, Job Performance, Values, Norms, Banking Industry

\section{INTRODUCTION}

Today's organization is predominantly dynamic as it poses large opportunities and challenges to the corporate practitioners and policy makers. Understanding such dynamism is very crucial to pursue the organizational strategic objectives. Banks also engaged in providing payment services, thereby facilitating all entities to carry out their financial transactions. Therefore, the soundness of banks is important, as it contributes towards maintaining confidence in the financial system, and any failure may 
have the potential to impact on activities of all other financial and non-financial entities, and finally the economy.

Organizational culture is a pattern of basic assumptions that are considered valid and that are taught to new member as the way to perceive, think, and feel in the organization. Robbins (2011) stated that a system of shared meaning held by members that distinguishes the organization from other organization as organizational culture. Organizational development has certain factors that improve sustainability on basis of effectiveness.

The improvement in productivity leads to employee commitment as norms, values and objectives helps in improving culture of an organization. The system of organization was based upon effective establishment of culture that keep learning environment strong. The performance of employees improves by establishment of strong culture of an organization.

The loyalty of employee depends on upon knowledge and awareness of culture that improves behaviour of organization (Brooks, 2006). Organization culture have first time been identified by Administrative Science quarterly (Pettigrew, 1979). The value and norms of employee's basis upon management identification that help in improving employee performance. The different attributes of culture have been arranged on basis of norms and attitudes which help in differentiating one firm from another. (Forehand and von Gilmer, 1964). The awareness of quality helps in improving organizational and employee development.
The banking industry operates in a very competitive environment and as a result, job performances are very useful for flexible and just-in-time responses to competitive challenges. Traditionally, the banking industry has been more focused toward quantitative and technology mechanisms and organizational culture has not been very highly prioritized. Results of this study indicate that they will benefit from a focus on fostering an innovative, open, and risk supporting organizational culture.

\subsection{Research Problem}

Organizational culture has become an important segment in an organization which directly influences the performance. There were several studies have been done in organizational culture and organizational identity, job attitudes, innovation strategy etc. Most of studies have been taken cultural types for investigating the impact between organizational culture and job performance. As clan culture, hierarchical culture, adhocracy culture and market culture. But there were few studies organizational cultural variables and job performance. Such as Cultural norms, values, beliefs, subcultures, leadership etc.

The relationship between organizational culture and performance has engaged the attention of researchers for many years (Zakari, Poku \& Owusu-Ansah 2013). While many culture researchers have devoted numerous articles to the nature and definitions of culture, relatively fewer articles have 
contributed towards culture and performance research (Lee \& $\mathrm{Yu}$ 2004). Majority of existing studies on organizational culture and performance have concentrated on developed countries (Zakari, Poku \& Owusu-Ansah 2013) and very little has been done in developing countries (Davidson, 2003 as cited in Zakari, Poku \& Owusu-Ansah 2013). Ojo (2009) emphasizes in his study that corporate culture is very important for every organization and that it has positive impact on employee job performance.

This is the gap researcher had identified and try to investigate more on that. The banking industry is the most competitive service industry in Sri Lanka. This competitive environment makes banking industry necessarily innovative, so the organizations in banking industry adopt innovations faster than their counterparts in any other service industry in Sri Lanka. Individual customers constitute a large part of banking portfolios in Sri Lanka. So many of the innovative practices target individual customers and online banking related products are among the most important new and innovative offerings in the banking industry.

\subsection{Research Objectives}

1. To identify how cultural norms have effects on job performance in a multinational banking industry

2. To identify how cultural values have effects on job performance in a multinational banking industry
3. To identify how subculture has effects on job performance in a multinational banking industry.

4. To identify cultural beliefs have effects on job performance in a multinational banking industry

\subsection{Significance of the study}

This study will significant for business level managers how to develop the favorable culture within the executive level employees and how they maintain satisfied employee pool within the organization. In the future the organizational culture takes value in effecting performance in the Bank and directly effects on the employee performance and their career development.

It also helps employer that effect behavior of the employee in the organization and set different goals for achieving it. This research is purely based on the different factors and show direct relationship and impact on employee job performance and will ensure to cover all the possible factors in the research.

Now a day's organization culture has generally been interrelated to management. (Kotter and Heskett, 1992). The two essential factors that lead to effective culture management include structural stability and integration of superior standard of organization culture. (Schein, 1995) Certain characteristics of organization culture have been established in which set of norms, values and beliefs helps in perfect association between them. (Hodgetts and Luthans, 2003) At different level of organization culture different background, ethics and racial 
differences impact upon performance. The similar organization culture with different backgrounds has common set of values and beliefs to be affected by organization systems. (Robbins \& Sanghi, 2007) The attraction of organization norms, values and beliefs have strong affect upon performance and sustainability. (Stewart, 2010) The norms of employees' impact upon sustainable performance and management of organization culture as it leads to attainment of profitability.

\section{LITERATURE REVIEW}

Organization culture is widely considered to be one of the most significant factors of organization variables. Every organization has its unique organization culture to differentiate them from others and the culture reflects the behavior of employees in organization. The challenge of today's managers is managing diverse cultures work force employees from which have significant influence on the behavior at work, managerial practices, organizational effectiveness and efficiency. Despite the importance to researchers, managers, and policy makers of how organization culture contributes to organization variables, there is uncertainty and debated about what is known and not known.

\subsection{Cultural values}

O'Reilly \& Chatman (1991), clarify Organizational culture as shared values that inform organizational members about how to behave appropriately. Organizations with a strong culture create clear and coherent values (Chatman \& Cha, 2002; Saffold, 1988) and expect that members agree with and care intensely about those values (Jackson, 1966; O'Reilly, 1989), even if core values emphasize dissent and creativity (Flynn \& Chatman, 2001; Sutton \& Hargadon, 1996). The cultural values have an ability of influencing organizational human activities. Hofstede (1998) also mentioned that it has an ability to guide the human activities. Every culture is having unique collection of values. Those values are having high capability of influencing people activities.

\subsection{Cultural norms}

According to the investigations of Kotter and Hesket (1992) most successful companies are those directed and managed within very strong cultural norms. The activities and missions of organizations that have worked well in the past and which translate into norms, behavior and expectations about what is desirable ways of thinking can influence organizational culture.

\subsection{Cultural beliefs}

Shared beliefs which are in directly opposite to the values and beliefs of the broader organizational culture recognized as countercultures, it mostly formed around a forceful manager or leader (Kerr, J., \& Slocum, J. W., Jr. 2005). This type of culture may be bearded by the firm whenever positively contributing to the improvement of the organizational performance. But it is considered as a danger for the original organizational culture. According to Deal and 
Kennedy (1982), Culture of organization is considered strong, where the greater part of the employees holds the same type of beliefs as concern to the organization.

\subsection{Subcultures}

Subcultures have certain properties that can even strengthen an organization's overall organizational culture. First, subcultures vary in the extent to which they disrupt the overarching culture. Second, subcultures often emerge in response to changing demands and can serve as an outlet for members to express conflict and dissent arising during turbulent times. Thus, subcultures may provide a mechanism for changing fewer central values. Indeed, that subcultures are potentially important with respect to affecting core values may further substantiate how difficult it is to change an organization's culture (Trice \& Beyer, 1984). Reducing change-induced disruption can be particularly advantageous if the overarching culture is strategically aligned and effective.

\subsection{Relationship between organizational culture and performance}

The relationship between organizational culture and performance has engaged the attention of researchers for many years (Zakari, Poku \& Owusu-Ansah 2013). While many culture researchers have devoted numerous articles to the nature and definitions of culture, relatively fewer articles have contributed towards culture and performance research (Lee \& $\mathrm{Yu}$ 2004). Majority of existing studies on organizational culture and performance have concentrated on developed countries (Zakari, Poku \& Owusu-Ansah 2013) and very little has been done in developing countries (Davidson, 2003 as cited in Zakari, Poku \& Owusu-Ansah 2013).

\section{METHODS}

This research study follows a quantitative research approach with an exploratory research design as this study is going to investigate the impact of the independent variable (Organizational Cultural Norms, Values, Beliefs and Subcultures) on the dependent variable (Employee Job Performance).

Accordingly, the Research Model is depicted as below,

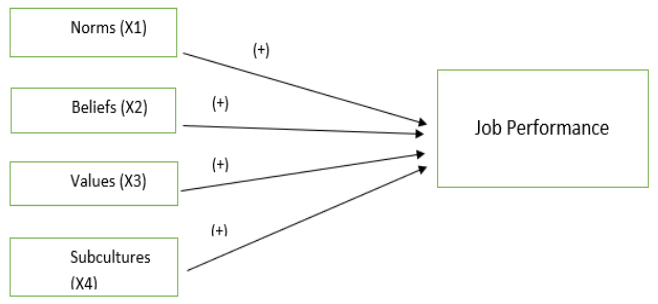

Figure 1. Research Model

Relevant data were collected through a self-administered questionnaire from bankers who were working in selected top 5 multinational banks in Colombo district. Accordingly, the sample consisted of 100 Executive level bankers were selected through Stratified random sampling method. Constructs of the questionnaire were operationalized through this rigorous literature review, and all scales were measured with five-point Likert scale. 
Collected data were analyzed using Statistical Package for the Social Sciences (SPSS) 21 version. Data were analyzed using regression to measure the impact of variables and ANOVA was used to test the fitness of the model.

\section{RESULTS}

Cronbach's Alpha test of reliability was applied to test the reliability and it indicates the values above 0.7 which means higher internal consistency of the research and the questionnaire. Kolmogorov test was used to test the normality and calculated significant value of normality tests is greater than $0.05(0.273>0.05)$ it can be concluded that data are normally distributed.

\subsection{Regression Analysis}

Table 1. Model Summary

\begin{tabular}{|l|l|l|l|l|l|}
\hline & R & $\begin{array}{l}\text { R } \\
\text { Squar } \\
\mathrm{e}\end{array}$ & $\begin{array}{l}\text { Adjusted } \\
\text { R Square }\end{array}$ & $\begin{array}{l}\text { Std. } \\
\text { Error of } \\
\text { the } \\
\text { Estimate }\end{array}$ & $\begin{array}{l}\text { Durbin- } \\
\text { Watson }\end{array}$ \\
\hline $\begin{array}{l}\text { Mo } \\
\text { del }\end{array}$ & $.749 \mathrm{a}$ & .561 & .542 & .46954 & 1.640 \\
\hline
\end{tabular}

The result from the Regression analysis shows the value of Pearson's correlation between organizational cultural variables and employees' performance is 0.561 . It means all the independent variables are describing $56.1 \%$ of Dependent variable.

Table 2. ANOVA Table

\begin{tabular}{|c|l|l|l|l|l|}
\hline Model & $\begin{array}{l}\text { Sum of } \\
\text { Squares }\end{array}$ & ff. & $\begin{array}{l}\text { Mean } \\
\text { Square }\end{array}$ & $\mathrm{F}$ & Sig- \\
\hline $\begin{array}{l}\text { Regres } \\
\text { sion }\end{array}$ & 26.236 & 4 & 6.559 & $\begin{array}{l}29.7 \\
51\end{array}$ & $\begin{array}{l}\text { Ob } \\
\text { Ob }\end{array}$ \\
$\begin{array}{l}\text { Residu } \\
\text { al } \\
\text { Total }\end{array}$ & 20.503 & 93 & .220 & & \\
\hline
\end{tabular}

If the Probability of the model ( $\mathrm{F}$ Statistic) of an overall significance test is less than the Significance level of $74 \%$ confidence level, then can reject the null hypothesis and accept that the model provides a better fit than the intercept-only model. Probability of the model (F Statistic) is $.000 \mathrm{~b}$ which indicates that overall model is significant under 0.1 significant level in determining the impact of convenience factors in organizational culture on employee job performance among bankers in Colombo district multinational banks.

\subsection{Hypothesis Testing}

Table 3. Coefficient Table

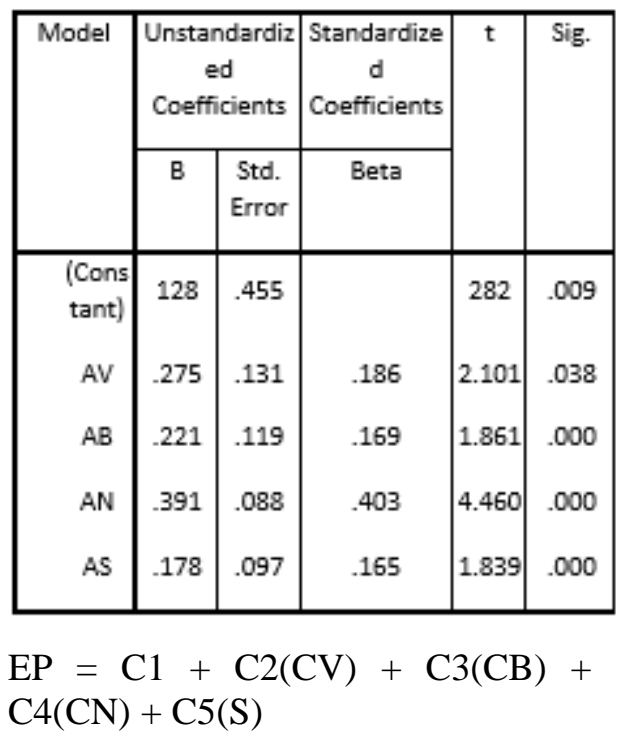

Where EP denotes employees' performance and has been treated as a dependent variable. On the other hand, (CV) Cultural Values, (CB) Cultural Believes, (CN) Cultural Norms, (S) Subcultures are independent variables in the model. In this model, $\mathrm{C} 1$ is intercepted, which shows EP is not influenced by $\mathrm{CV}, \mathrm{CB}, \mathrm{CN}$ and $\mathrm{S}$. 
According to the above results, $\mathrm{C} 2$, C3, C4 and C5 are significant, which define that organizational culture significantly affects employees' performance. Moreover, the value of adjusted $\mathrm{R}$ square is 0.542 , which represents that 54.2 per cent variation in employee performance is explained by organizational cultural variables. Analysis of variance table shows the significant level at 0.000 , which indicates that the applied model is a good fit. (Table 3)

$\mathrm{EP}=128+0.275 \mathrm{CV}+0.221 \mathrm{CB}+$ $0.391 \mathrm{CN}+0.178 \mathrm{~S}$

Table 4. Correlations

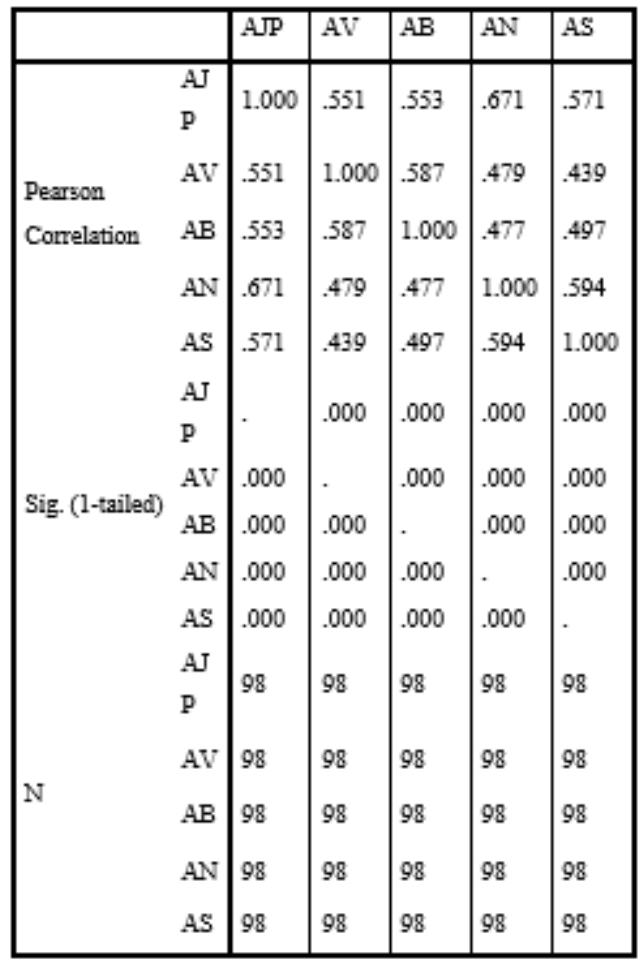

$\mathrm{H}_{1} \mathrm{a}$ - There is a significant impact of organizational cultural values on employee job performance in multinational banking employees in Colombo district. According to Pearson's Correlation table 3, the relationship between cultural values and employee job performance was significant since, $\mathrm{P}=0.000<0.05$. Also, as per table 4 , the $\mathrm{P}$ value of cultural values was 0.551 and has significant impact on employee job performance. Therefore, the conclusion was derived as there is a significant impact of cultural values on employee job performance in multinational banking sector employees in Colombo district. Then, the alternative hypothesis was accepted.

$\mathrm{H}_{2} \mathrm{a}$ - There is a significant impact of organizational cultural believes on employee job performance in multinational banking employees in Colombo district. According to Pearson's Correlation table 4, the relationship between cultural values and employee job performance was significant since, $\mathrm{P}=0.000<0.05$. Also, the $B$ value of cultural values was 0.553 and has significant impact on employee job performance. Therefore, the conclusion was derived as there is a significant impact of cultural values on employee job performance in multinational banking sector employees in Colombo district. Then, the alternative hypothesis was selected.

$\mathrm{H}_{3} \mathrm{a}$ - There is a significant impact of organizational cultural norms on employee job performance in multinational banking employees in Colombo district. According to Pearson's Correlation table 4, the relationship between cultural values and employee job performance was significant since, $\mathrm{P}=0.000<0.05$. Also, 
the $B$ value of cultural values was 0.671 and has significant impact on employee job performance. Therefore, the conclusion was derived as there is a significant impact of cultural values on employee job performance in multinational banking sector employees in Colombo district. Then, the alternative hypothesis was selected.

$\mathrm{H}_{4} \mathrm{a}$ - There is a significant impact of organizational subcultures on employee job performance in multinational banking employees in Colombo district. According to Pearson's Correlation table 4, the relationship between cultural values and employee job performance was significant since, $\mathrm{P}=0.000<0.05$. Also, the $B$ value of cultural values was 0.571 and has significant impact on employee job performance. Therefore, the conclusion was derived as there is a significant impact of cultural values on employee job performance in multinational banking sector employees in Colombo district. Then, the alternative hypothesis was selected.

\section{DISCUSSION FINDINGS}

Hypotheses testing results reveal that all of the organizational cultural variables (values, norms, believes and subcultures) are related to employee job performance (contribution, efficiency). Where the highest influencing variable is cultural norms. And least influencing variable is subculture. The relationship was confirmed in this study based on correlation and regression analyses results. The hypotheses related the cultural variables-performance were confirmed either. Beta coefficients reflected significant positive sign for culture (norms, values, believes and subcultures) and performance relationship and significant positive sign for the culture and job Performance. The result from this study also supports the empirical studies that showed the indirect effect of organizational culture on performance (Han et al., 1998; Tseng, 2010; Zheng et al., 2010).

Research findings provide direct support for these theoretical and empirical studies, it concludes that organizational cultural variables affect performance outcomes considering the relatively small sample size and measuring the performance based on figures in the study. Instead of jumping to a conclusion that there is direct relationship between organizational culture and performance outcomes, as well the positive impact on job performance. it is more reasonable to suggest that it is advisable to further explore direct and indirect culture-performance relationship in different contexts with different measurements and research designs. Organizational believes and subcultures have positive impact on employee job performance but not as much as norms and values. Managers need to consider organizational believes and how employees are trusting organizational structure on their point of view. Specially managers need to address ethical conflicts and try to give best solutions for that.

Subcultures create working place more enjoyable with their unique values. But managers should combine 
these all subcultures for one direction. Since organizational vision, mission, goals and objectives are same for all.

\section{CONCLUSION}

Every person or employee in the organization has own different values and beliefs that he/she works with them. Whenever join any organization he/she allowed himself to internalize first with the organization's culture to know whether he come up with them or not. Culture is being investigated to impact of organizational process. Organizational culture has a significant impact on the performance of employees that can cause to improve in the productivity and enhance the organizational performance. Results of studies mostly show positive association between strong culture and performance improvement.

Overall influence of organizational culture on job performance as identified in a number of past researches carried out in non-Asian cultures (Aycan et al., 1999; Lund, 2003; Ogbonna \& Harris, 2000; Shehzad et al., 2013) have been substantiated in Saudi cultural environment as well. However, the impact of each element on the job performance was not found similar to these same researches.

Based on the findings, the study recommends that the management on multinational banks should consider adopting involvement culture traits as an organizational culture during job performance. This will allow the management to create a comprehensive understanding that can be leveraged to influence stakeholders and create better decisions. The study recommends that the management keeps on adapting to change as well as re-assessing the effect and frequency of mitigation measures adopted. This will help to identify whether the adopted counteractive culture are making any acceptable difference.

Based on this study researcher can conclude that organizational culture has a positive impact on the employee's job performance. Research shows that every individual in the organization has different culture and he/she first try to adjust him with the norms and values of the organization. The adoption of culture of the organization is helpful for the employees to do their work efficiently and effetely. Positive development is easier to achieve when everyone is on a common path in the organization.

\section{REFERENCES}

Brooks, I. (2006). Organizational Behavior: Individuals, Groups and Organization. Essex: Pearson Education Limited.

Chatman, J. A. \& Cha, S.A. In press. Leading through organizational culture. In, S. Chowdhury (Ed.), Next generation business series: Leadership: Financial TimesPrentice Hall Publishers.

Deal, T. E., \& Kennedy, A. A. (1982). Corporate Cultures, the Rites and Rituals of Corporate Life. Massachusetts: Addison-Wesley.

Flynn, F., \& Chatman, J. A. (2001). Strong cultures and innovation: Oxymoron or opportunity? In 
Cartwright, S., Cooper, C., Earley, C., Chatman, J., Cummings, T., Holden, N., Sparrow, P. \& Starbuck, W. et al., (Eds.), International handbook of organizational culture and climate: 263-287. Sussex: John Wiley \& Sons.

Forehand, G. A. and Von Gilmer, (1964). Environmental Variations in Studies of Organizational Behavior. Psychological Bulletin, 62, 361-382.

Han, Z.S., Enslen, H., Hu, X., Meng, $\mathrm{X}$., Wu, I.H., Barrett, T., Davis, R.J., Ip, Y.T. (1998). A conserved mitogen-activated protein kinase pathway regulates Drosophila immunity gene expression. Mol. Cell. Biol. 18(6): 3527--3539.

Hofstede, G. (1998). Identifying organizational subcultures: An empirical approach. Journal of Management Studies, 35: 1-12.

Jackson, J. (1966). A conceptual and measurement model for norms and roles. Pacific Sociological Review, 9: 35-47.

Kerr, J., \& Slocum, J. W. (2005). Managing corporate culture through reward systems. Academy of Management Executive, 19(4), 130-137. https://doi.org/10.5465/ame.2005. 19417915

Kim Jean Lee, S. and Yu, K. (2004), "Corporate culture and organizational performance", Journal of Managerial Psychology, Vol. 19 No. 4, pp. 340-359. https://doi.org/10.1108/02683940 410537927

Kotter, J. P. \& Heskett, J. L. (1992). Corporate culture and performance. New York: Free Press.

O'Reilly, C. A.; Chatman, J., \& Caldwell, D. F. (1991). People and Organizational Culture: A

Ojo, Olu (2003). Fundamentals of Research Methods, Lagos: Standard Publications.

Pettigrew, A. (1979). studying organizational culture. Administrative Science Quarterly, 24, 570-581.

Robbins, Stephen P., Timothy A. Judge. (2011), Organizational Behavior. New Jersey: Pearson Prentice Hall,

Saffold, G. S. (1988). Culture traits, strength, and organizational performance: Moving beyond "strong" culture. Academy of Management Review, 13: 546558

Sutton, R. I., \& Hargadon, A. (1996). Brainstorming groups in context: Effectiveness in a product design firm. Administrative Science Quarterly, 41(4), 685-718. https://doi.org/10.2307/2393872

Trice, H.M., \& Beyer, J. M. (1984). Studying organizational cultures through rites and ceremonials Academy of Management Review, 9: 653-669.

Tseng, S. (2010) The Correlation between Organizational Culture 
and Knowledge Conversion on Corporate Performance. Journal of Knowledge Management, 14, 269-284.

https://doi.org/10.1108/13673271

011032409

Zakari, M., Poku, K. and OwusuAnsah, W. (2013) Organisational Culture and Organisational Performance: Empirical Evidence from the Banking Industry in Ghana. International Journal of Business, Human and Technology, 3, 95-107. 